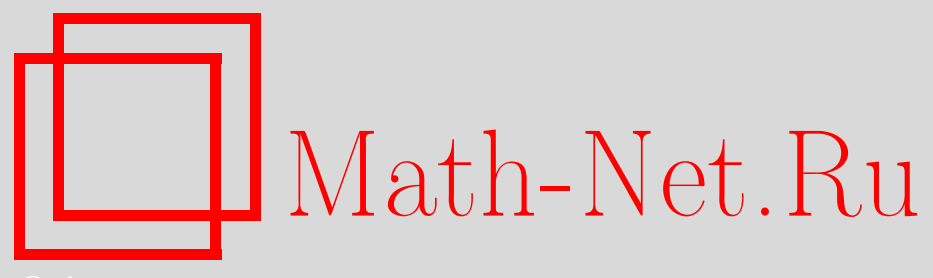

С. Дворянинов, Фантастика и реальность, Квант, 2021, номер 7, 36

DOI: https://doi.org/10.4213/kvant20210703

Использование Общероссийского математического портала Math-Net.Ru подразумевает, что вы прочитали и согласны с пользовательским соглашением http://www.mathnet.ru/rus/agreement

Параметры загрузки:

IP : 54.147 .182 .235

26 апреля 2023 г., $15: 32: 13$

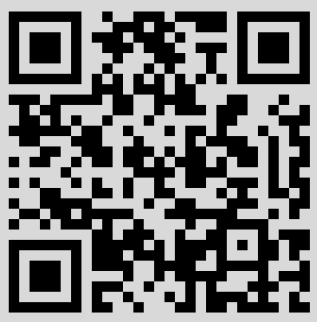




\section{Фантастика и реальность}

С.ДВОРЯНИНОВ

ы помните, как в книге Н.Н. Носова «Незнайка на Луне» ее герои представляли строение Луны? Они считали Луну пустотелой, и поэтому Знайка так мечтал о новых путешествиях:

«Хорошо бы построить большой межпланетный корабль, взять значительный запас пищи и воздуха и устроить длительную экспедицию на Луну. Надо полагать, что во внешней оболочке Луны имеются отверстия в виде пещер или кратеров потухших вулканов. Сквозь эти отверстия можно будет проникнуть внутрь Луны и увидеть ее центральное ядро. Если это ядро существует, а оно без сомнения существует, то лунные коротышки живут на его поверхности. Между внешней оболочкой и центральным ядром Луны, наверно, сохранилось достаточное количество воздуха, поэтому условия жизни на поверхности ядра должны быть вполне благоприятными для коротышек».

Но для жизни на такой Луне коротышкам непременно потребовалась бы энергия. Как же ее можно получить? Давайте продолжим фантазии Знайки.

Каждое тело массой $m$, находящееся на высоте $h$ над поверхностью Земли, обладает потенциальной энергией $W=m g h$. Так и каждый камень на внешней оболочке Луны обладает потенциальной энергией относительно лунного ядра. Погрузили камень в корзину с веревкой, а веревку намотали на ротор электрогенератора - и все! Корзина поехала вниз, ротор завертелся, электрическая энергия по проводам потекла куда надо. (По этому же принципу действуют и гири старинных часов - их потенциальная энергия заставляет работать часовой механизм.) Конечно, одной корзиной не обойтись, несколько корзин надо разместить на кольцевой ленте - подобно обычному транспортеру (аналогичным образом закреплены ступени эскалатора в метро).

Вы скажете: Знайка, Незнайка, пустотелая Луна - несерьезно это, детские фантазии! А вот и нет. Сказанное об использовании потенциальной энергии уже давно реализовано в конструкции водных фуникулеров для подъема людей на гору. Только в этом случае вместо камней используют воду, а вместо корзины для камней бак под вагончиком фуникулера.

Подобно обычному фуникулеру, два вагончика водного фуникулура связаны тросом. На вершине горы в специальный бак одного из вагончиков заливают воду, а внизу из бака другого вагончика воду выливают. При этом равновесие нарушается, и верхний вагон перевешивает нижний. Затем тормоза отпускают, и вагончики поехали: тяжелый с водой - вниз, легкий без воды - верх. Вот и все. Первые такие фуникулеры были построены почти полтора века назад, некоторые действуют до сих пор.

Что же, получается вечный двигатель? Нет, конечно. Кончится вода на вершине горы - фуникулер нечем будет заправлять. А оказывается вода на вершине за счет энергии Солнца - вода на земле испаряется, поднимается вверх и в виде дождя или снега падает на вершину горы.

DOI: https://doi.org/10.4213/kvant20210703

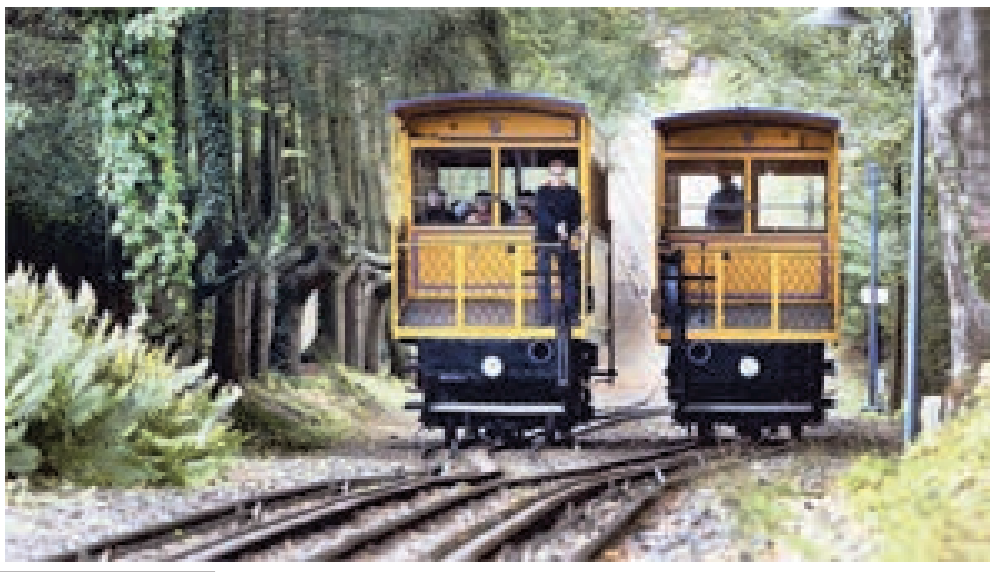

